\title{
BACTERIOPLANKTON METABOLISM IN HYDROELECTRIC RESERVOIRS
}

\author{
Fabio Roland ${ }^{1 *}$, André C. P. Cimbleris ${ }^{2}$, Lúcia M. Lobão ${ }^{1,3}$ \& Luciana O. Vidal \\ ${ }^{1}$ Universidade Federal de Juiz de Fora, Instituto de Biologia, Laboratório de Ecologia Aquática, Campus Universitário, Rua José Lourenço Kelmer, \\ $\mathrm{s} / \mathrm{n}^{\circ}$, Bairro São Pedro, Juiz de Fora, MG, Brasil, CEP:36.036-900. \\ ${ }^{2}$ Furnas Centrais Elétricas S. A., Assessoria de Políticas e Estudos Ambientais, Rua Real Grandeza 219, Rio de Janeiro, RJ, Brasil, CEP:22.281-900. \\ ${ }^{3}$ Universidade Federal do Rio de Janeiro, Programa de Pós-Graduação em Ecologia, Cidade Universitária, CCS, Ilha do Fundão, Rio de Janeiro, RJ, \\ Brasil, CEP: 21941-540. \\ E-mails: fabio.roland@ufjf.edu.br, andrec@furnas.com.br, lu.mlobao@gmail.com, lovidal@ig.com.br
}

\begin{abstract}
Reservoirs are anthropogenic aquatic systems accounting to a substantial portion of the contemporary distribution, and dynamic, of freshwater systems across a wide geographical gradient throughout the Globe, with potential to increase its participation due to the growth of world's economy and need for energy. These systems may play an important role, poorly documented and currently controversial, to the regional to global balance of greenhouse gases. We studied bacterial metabolism (production and respiration) in eight large hydroelectric reservoirs in Brazil following a gradient in area, age since flooding and residence time. Seven of which located in tropical savanna and the other located in the tropical forest region. The results indicate similar bacterial production (BP) and bacterial respiration (BR) variability, with higher BR rates in relation to BP. Bacterial growth efficiency also showed a wide range (2.5 to $28.7 \%$ ), besides a low mean value (13\%). Reservoir age was the best predictor for BGE, as well as for the specific bacterial respiration (SBR). The older reservoir showed the lower BGE and the higher SBR. The bacterial metabolism rates in the pelagic regions of tropical Cerrado hydroelectric reservoirs do not differ from natural freshwater system concerning BP, BR and BGE; however, it is differentiated by the factors driven those rates.
\end{abstract}

Keywords: Hydroelectric tropical reservoirs; carbon budget; bacterial production; bacterial respiration; bacterial growth efficiency.

\section{RESUMO}

\section{METABOLISMO DO BACTERIOPLÂNCTON EM RESERVATÓRIOS DE HIDRELÉTRICAS.}

Reservatórios são sistemas aquáticos artificiais que ocupam uma importante parte da distribuição e dinâmica atual dos corpos d'água continentais distribuídos ao longo do Globo, com potencial aumento de sua participação devido ao crescimento econômico mundial e a demanda energética. Estes sistemas tem um importante papel, pouco documentado e frequentemente controverso, para o balanço de gases de efeito estufa (GEE) regional e global. Neste estudo foi avaliado o metabolismo bacteriano (respiração e produção) em oito grandes reservatórios de hidrelétricas no Brasil, em um gradiente de área, idade desde o enchimento e tempo de residência. Sete deles estão localizados no Cerrado e apenas um na região de Mata Atlântica. Os resultados indicam similar variabilidade da produção $(\mathrm{PB})$ e da respiração bacteriana $(\mathrm{RB})$, sendo observadas maiores taxas de $\mathrm{RB}$ relativamente à $\mathrm{PB}$. A eficiência de crescimento bacteriano (ECB) também apresentou uma grande variação (2,5 a 28,7\%), além de um baixo valor médio (13\%). A idade do reservatório foi o melhor preditor da ECB, bem como da respiração bacteriana específica (RBE). As taxas metabólicas bacterianas na região pelágica dos reservatórios de hidrelétricas, localizados no Cerrado, não diferiram dos valores encontrados para $\mathrm{PB}, \mathrm{RB}$ e ECB em sistemas naturais, entretanto diferem quanto aos fatores direcionadores destas taxas.

Palavras-chave: Reservatórios tropicais; balanço de carbono; produção bacteriana; respiração bacteriana; eficiência de crescimento bacteriano. 


\section{INTRODUCTION}

The analysis of ecological efficiencies, expressed as ratio between production and respiration, identified the main route of carbon in ecosystems (Roland \& Cole 1999). Bacterial growth efficiency (BGE) varies widely in aquatic systems and generally the values are low (del Giorgio et al. 1997, Kritzberg et al. 2005, del Giorgio et al. 2006, Jansson et al. 2006). Besides, there are few studies about measurements of bacterial respiration (Cimbleris \& Kalff 1998, Roland \& Cole 1999, Kritzberg et al. 2005, del Giorgio et al. 2006). Bacterial respiration (BR) show higher rates than bacterial production (BP), which reflects in a low BGE values. Earlier studies in different aquatic ecosystems have mainly explained the values of BGE by variations in BP rates (Roland \& Cole 1999, Kritzberg et al. 2005). Although the regulation of bacterial growth and production rates has received a great deal of attention in the past, the factors that control bacterial respiration, and its relationship to bacterial production (growth efficiency) remain poorly understood (Jahnke \& Craven 1995, Williams 2000).

Reservoirs are anthropogenic aquatic systems that now account to a substantial and increasing portion of the World's freshwater. These systems may play an important, but poorly documented and currently controversial, role in the regional to global balance of greenhouse gases. According to St. Louis et al. (2000) reservoirs are a potential source of carbon dioxide $\left(\mathrm{CO}_{2}\right)$ to the atmosphere. Authors have been assumed reservoirs functioning as a lake (Thornton 1990, Dumestre et al. 1999). However, in an integrated perspective for dynamic process, different natural and anthropogenic physical forces may determine singular ecological patterns for reservoirs. Both morphometric features and watershed size, as well the dam operation, are strong drivers of the temporal ecological evolution of reservoirs since the landscape are flooded. The terrestrial flooded biomass is an important autochthonous source of carbon to be metabolized during the first stages of the reservoirs.

Carbon cycle and metabolic balance are strongly associated with the two major processes primary production and respiration Algal biomass is usually bottom up controlled by resources (light and nutrients, mainly $\mathrm{N}$ and $\mathrm{P}$ ), but also by top down processes. Regulation of respiration is less known and is considered related to labile organic carbon. Different sources of allochtonous carbon (terrestrial particulate $\mathrm{C}$ and terrestrial DOC) and autochtonous carbon (macrophytes, phytoplankton and bentic algae) make uncoupled ecosystem respiration and phytoplankton primary production (Cole et al. 2000). Despite most DOC being relatively refractory, there are evidences that some of this DOC is respired when into the lakes (Duarte \& Agusti 1998, del Giorgio et al. 1997). It is assumed that the excess of $\mathrm{CO}_{2}$ in aquatic ecosystems is mainly the result of allochthonous organic matter (del Giorgio \& Peters 1993, Sobek et al. 2005). The role of both heterotrophic and autotrophic activity along reservoirs has been reported in studies of subtropical, tropical and temperate areas (Robarts \& Wicks 1990, Di Siervi et al. 1995, Richardot et al. 2000, Bukaveckas et al. 2002, Raymond \& Cole 2003, Lauster et al. 2006, Jugnia \& De'vaux 2008, Jugnia et al. 2006, Finlay et al. 2009). On the other hand, there are no studies taking respiration and BGE in combination in hydroeletric reservoirs.

The emission of GHG gases by reservoirs is considered as a consequence of the processes of respiration and decomposition of flooded organic matter (Tremblay et al. 2004). Bacterial respiration of organic matter has been addressed as the main contributor to inorganic carbon to the system. Moreover, the contribution from watershed, tributaries, depth, size/volume, flooded biomass, residence time, operation (where the water pass through the dam) must be considered. In temperate systems, the mineralization by bacterial action and the action of light can reach $70 \%$ of $\mathrm{CO} 2$ production in the water (Jonsson et al. 2001). Therefore, the study of bacterial metabolism in the reservoirs is crucial to understanding the emission of greenhouse gases from these systems, which comprise $2 \%$ of the global land surface area.

In the sense, we focused on bacterial metabolism approaching both production and respiration rates in seven tropical hydropower reservoirs. We aimed that (1) BGE is major controlled by production and (2) Bacterial metabolism is strongly driven by reservoir age, flushing, thermal structure, and eutrophication.

\section{METHODS}

The present study was part of a five year project (Carbon budget in FURNAS hydroelectric reservoirs) 
developed from 2003 to 2008, which has been investigated the carbon cycle and GHG emissions in reservoirs, ranging from 40 to $1784 \mathrm{~km}^{2}$, located in the central and southeast regions of Brazil.

\section{STUDY SITES AND SAMPLING}

Eight reservoirs are included in this study (Figure

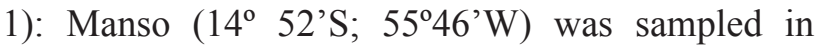
two different moments - 2003/2004 - MA1 and 2006/2007 - MA2; Serra da Mesa-SER (13 49'S; $\left.48^{\circ} 18^{\prime} \mathrm{W}\right)$; Corumbá-COR (17 $59^{\circ} \mathrm{S}$; $\left.48^{\circ} 31^{\prime} \mathrm{W}\right)$; Itumbiara -ITU (18 $24^{\prime} \mathrm{S}$ '; $\left.49^{\circ} 05^{\prime} \mathrm{W}\right)$; Luiz Carlos Barreto de Carvalho, LCB (20 $00^{\circ} \mathrm{S}$; $\left.47^{\circ} 16^{\prime} \mathrm{W}\right)$; Furnas-FUR (20 39'S; $\left.46^{\circ} 18^{\prime} \mathrm{W}\right)$; Mascarenhas de Moraes-MSM (20 $16^{\prime}$ 'S; $\left.47^{\circ} 03^{\prime} \mathrm{W}\right)$ and Funil-FUN

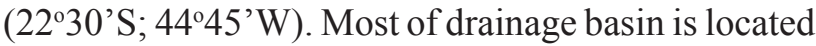
on very poor soils, where organic carbon density in the soils ranged from 4.5 to $5.3 \mathrm{~kg} \mathrm{~km}^{2}$, if compared to mean values in rich Amazonian soils (mean=7.2; range $=6.1-9.2 \mathrm{~kg} \mathrm{~km}^{2}$ ) (http://www.sage.wisc.edu).

SER reservoir belongs to the Tocantins-Araguaia hydrographical region and it is the largest Brazilian reservoir, in volume, and the fifth, in area. It is located on an asbestos rich basin and the main tributary is Tocantins river. MAN reservoir is about 2.5 times smaller in area than SER; it belongs to Paraná hydrographical region and the main tributary is Manso river. COR and ITU reservoirs belong also to Paraná hydrographical region and main rivers are, respectively, Corumbá and Paranaíba. FUR, LCB and MSM are reservoirs in cascade in Grande river, also in the Paraná hydrographical region. FUN reservoir is located at a very industrial and populated area and the main tributary is Paraiba do Sul river, which belongs to the Coastal Southeast hydrographical region, draining to the Atlantic Ocean.

All the eight reservoirs are used for power generation and some of them also for drinking water. The withdrawal water is close to the bottom in COR and FUN and from intermediate water column in the others. They are different in age, size and hydrology. MAN, SER and COR are young $(<11$ years) and the others are relatively old ( 28 to 51 years). FUN, LCB and COR are relatively small in area (28 to 55 $\mathrm{km}^{2}$ ), MSM and MAN are intermediate (250 to 357 $\mathrm{km}^{2}$ ) and ITU, SER and FUR are large reservoirs (719 to $1342 \mathrm{~km}^{2}$ ). SER, MAN and FUR have high theoretical residence time (1.18 to 2.11 years), while
LCB, COR and FUN are high (0.05 to 0.15 years) or intermediate flushing systems ( 0.4 to 0.44 years). Samples were taken during three seasons (pre-rainy, November; after-rainy, March and dry, July) in SER and first sampling in Manso, MA1 (2003-2004), in COR and ITU (2004-2005), in FUR, MSM and LCB (2005-2006) and in FUN and the second sampling in Manso, MA2 (2006-2007). The depth of PAR distribution was measured using a spherical sensor in a LI-COR radiometer, model LI-1000.

\section{ENVIRONMENTAL DATA}

All reservoirs are deep (maximum depth $=38$ to 100 meters) and most are mesotrophic, based on chlorophyll- $a$, total-P and total $\mathrm{N}$ concentrations. FUN is the exception with eutrophic waters and has a long standing cyanobacteria bloom in the last 10 years (Soares et al. 2008). The limit of euphotic zone was measured at $1 \%$ of light extinction. The mixing zone was defined through temperature profiles measured with a Yellow Springer, 6920 probe. Sample for limnological parameters, phytoplankton and bacterioplankton carbon were taken using Van Dorn bottle at surface, middle and limit of mixing zone.

\section{BACTERIA CARBON ANALYSES}

Samples for carbon content in bacterioplankton were fixed immediately in the field with formalin at $40 \%$ in the proportion of 1:9 (final concentration in the sample $=4 \%$ ). Samples for bacterial abundance (cells per $\mathrm{mL}$ ) were stained with acridine orange and filtered trough Nucleopore black filters $(0.2 \mu \mathrm{m}$ pore size) according to Hobbie et al. (1977) and estimated at a fluorescence microscopy (Olympus BX 60), in 20 random fields.

Phytoplankton and bacterial respiration were measured in dissolved oxygen consumption experiments (24 hours dark incubation). Samples were taken at the same 5-depth profile and filtered in a net $(68 \mu \mathrm{m}$ mesh) in order to retain planktonic grazers. After, sub-samples were filtered in 0.7 $\mu \mathrm{m}$ Whatmann filters for bacteria treatment. The unfiltered sample originated the total consumption (bacteria+phytoplankton). The initial control samples were immediately fixed with Winkler reagents. After incubation, samples were fixed with Winkler 


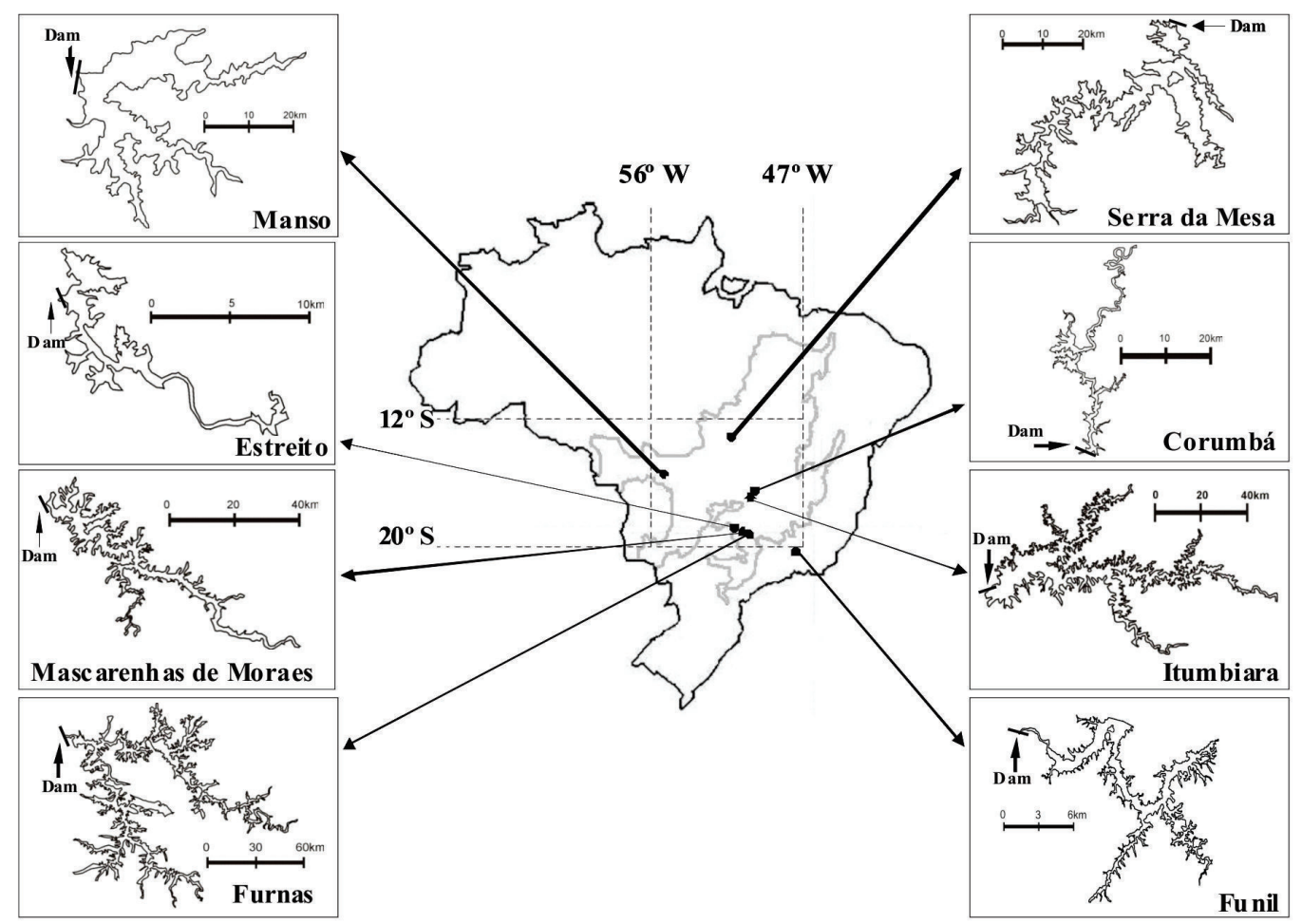

Figure 1. Location and maps of the eight reservoirs showing the sampling stations (Dam).

Figura 1. Localização e mapas dos oito reservatórios amostrados, destacando os pontos de amostragem (barragem).

reagents and dissolved oxygen concentration was determined by spectrophotometric Winkler technique according to Roland \& Cole (1999) in a Micronal B542 spectrophotometer. The oxygen consumption data were converted to carbon respired assuming a respiratory quotient (RQ) of 1.

Bacterioplankton production were measured using Smith \& Azam (1992) microcentrifuge modification of the $\left[{ }^{3} \mathrm{H}\right]$-leucine method (Kirchman et al. 1985) in all the 5-depth profile samples. The samples were incubated with $59 \mathrm{nM}$ final concentration of $\left[{ }^{3} \mathrm{H}\right]$ leucine (63 $\mathrm{Ci} \mathrm{mmol}^{-1}$, Amershan) during $45 \mathrm{~min}$. Incubations were ended by adding $0.3 \%$ of $50 \%$ TCA. Zero-time controls (blank) were fixed with 50\% TCA immediately after adding labeled leucine. Following incubation, the samples were centrifuged $[14,000$ rpm $(17,000 \times \mathrm{g}) ; 10 \mathrm{~min}]$ and the supernatant was discarded. Subsequently, $1.5 \mathrm{~mL}$ of $5 \%$ TCA were added and the samples were centrifuged during 10 min at 14,000 rpm; afterwards, the supernatant was withdrawn. A scintillation cocktail was added, the centrifuge tubes were placed in scintillation glass vials, and the radioactivity was determined using a LS 6500 Beckman Coulter. Bacterial production was calculated from disintegration per minute (dpm) to protein according to Simon \& Azam (1989).
Bacterial growth efficiency (BGE) was estimated as the quotient between bacterial production and the sum of bacterial production and bacterial respiration $[\mathrm{BGE}=\mathrm{BP} /$ (BP+BR).

\section{STATISTICAL ANALYSES}

Spearman correlations were undertaken to identify the potential relationships between bacterial variables (BP, $\mathrm{BR}$ and $\mathrm{BGE}$ ) and others variables such as age, residence time, DOC, TP, TN, chlorophyll- $a$ and GPP. Furthermore, we ran simple and multiple regressions and the equations were verified by stepwise forward $\&$ backward analysis, Akaike Information Criteria (AIC) being used to select the best regression model. T-Test was used to check the difference between BP and BR coefficients of variations. One-way ANOVA and Tukey-Kramer multiple comparison tests were used to test for differences in mean values of BP and BR among reservoirs.

\section{RESULTS}

\section{ENVIRONMENTAL DATA}

Hydrology is mainly dependent on precipitation and water management. Three of the eight reservoirs were low 
flushing (MAN, SER and FUR) and the others are high or intermediate flushing (0.05-0.4 years). Average of the residence times (reservoir volume/affluent discharge), calculated from daily data of the sampling month, were variable in some reservoirs or not such as in FUN, LCB e MSM. Higher residence times were observed during dry season in MA1, SER and FUR (Table 1). Three patterns of mixing regime were found at the dam sampling station measured in each sampling date (data not shown): i) systems stratified during all samplings (SER, FUR, FUN and MA2); ii) system stratified, but totally mixed during the winter (MA1); and iii) systems stratified with a deepening of the mixing zone until about half of the maximum depth, in at least one sampling season which in general occurred during the winter (ITU, COR, MSM, and LCB). The first information which emerged from the light measurements is that euphotic zone in all reservoirs, on average, is only 10 to $31 \%$ of the total water column at the dam sampling station. However, if this relative insolation in surface waters is expressed in relation to the mixing zone $\left(\mathrm{z}_{\mathrm{eu}}: \mathrm{z}_{\text {mix }}\right)$, on average, 63 to $89 \%$ of the mixing zone was into the euphotic zone in most of reservoirs. Only COR and FUN showed lower average values $(\sim 43 \%)$.

Table 1. General features of the eight reservoirs. Area and volume correspond to the respective year of study; maximum depth. euphotic and mixing zones are average among seasons (pre-rainy. pos-rainy and dry) at the station near to the dam; instantaneous residence time is daily average during the sampling month. MA1 = Manso sampled in 2003-2004; SER=Serra da Mesa; MA2 = Manso sampled in 2006-2007; COR=Corumbá; ITU=Itumbiara; LCB=Luiz Carlos Barreto; FUN=Funil; MSM=Mascarenhas de Moraes. Reservoirs ordered from the youngest to the oldest.

Tabela 1. Características gerais dos oito reservatórios. Área e volume correspondem ao ano de estudo; profundidade máxima. zona eufótica e de mistura são a média das estações (antes e após o período chuvoso e seca) na estação próxima da barragem; tempo de residência foi medido diariamente durante o mês de amostragem. MA=amostragem em Manso entre 2003 e 2004; SER=Serra da Mesa; MA2=amostragem em Manso entre 2006-2007; $C O R=$ Corumbá; ITU=Itumbiara LCB=Luiz Carlos Barreto; FUN=Funil; MSN=Mascarenhas de Moraes. Reservatórios foram ordenados dos mais jovens para os mais velhos.

\begin{tabular}{|c|c|c|c|c|c|c|c|c|c|c|}
\hline \multicolumn{11}{|c|}{ RESERVOIRS } \\
\hline & & $\begin{array}{c}\text { Manso } \\
1\end{array}$ & $\begin{array}{c}\text { Serra } \\
\text { da } \\
\text { Mesa }\end{array}$ & $\begin{array}{c}\text { Manso } \\
2\end{array}$ & Corumbá & Itumbiara & L.C.B. & Funil & Furnas & $\begin{array}{c}\text { Mascarenhas } \\
\text { de Moraes }\end{array}$ \\
\hline $\begin{array}{l}\text { Date of } \\
\text { Operation }\end{array}$ & & 2000 & 1998 & 2000 & 1997 & 1980 & 1969 & 1969 & 1963 & 1957 \\
\hline Área $\left(\mathrm{km}^{2}\right)$ & & 357 & 898 & 357 & 55 & 719 & 45 & 26.9 & 1342 & 250 \\
\hline Volume $\left(\mathrm{km}^{3}\right)$ & & 5.6 & 24.3 & 5.6 & 1.2 & 15.1 & 1.3 & 0.53 & 20.7 & 3.8 \\
\hline $\begin{array}{l}\text { Maximum Depth } \\
\text { (m) }\end{array}$ & & 47 & 100 & 38 & 48 & 76 & 55 & 45 & 89 & 43 \\
\hline $\begin{array}{l}\text { Euphotic Zone } \\
\text { (m) }\end{array}$ & & 7.0 & 9.3 & 11.7 & 3.7 & 11.5 & 11.0 & 5.4 & 10.7 & 11.3 \\
\hline Mixing Zone (m) & & 26.8 & 10.5 & 15.5 & 11.7 & 21.3 & 16.7 & 12.3 & 16.7 & 18.0 \\
\hline \multirow{3}{*}{$\begin{array}{l}\text { Instantaneous } \\
\text { Residence Time } \\
\text { (years) }\end{array}$} & $\begin{array}{l}\text { Pré- } \\
\text { rainy }\end{array}$ & 3.41 & 3.64 & 1.81 & 0.24 & 0.38 & 0.05 & 0.08 & 0.90 & 0.14 \\
\hline & $\begin{array}{l}\text { Post- } \\
\text { rainy }\end{array}$ & 1.34 & 0.46 & 1.10 & 0.05 & 0.22 & 0.04 & 0.12 & 0.58 & 0.10 \\
\hline & Dry & 7.68 & 4.57 & 1.09 & 0.13 & 0.44 & 0.05 & 0.06 & 1.86 & 0.17 \\
\hline $\begin{array}{l}\text { Theoretical } \\
\text { Residence Time } \\
\text { (years) }\end{array}$ & & 1.18 & 2.11 & 1.18 & 0.11 & 0.40 & 0.05 & 0.15 & 1.38 & 0.14 \\
\hline
\end{tabular}

\section{BACTERIA DATA}

\section{Bacterial Abundance}

Bacterial Abundance (BA) integrated in the zmix and seasonal period varied among reservoirs (Figure 2). The bacterial abundance was significantly higher $(p<0.05)$ in the youngest reservoirs $\quad(\mathrm{MA} 1=0.98, \quad \mathrm{SER}=1.30, \quad \mathrm{COR}=1.11$ and ITU $=0.96$ ). In the oldest reservoirs bacterial abundance varied between 0.28 (MSN) and 0.30 (cells $10^{6} \mathrm{ml}^{-1}$ - L.C.B.). There was a tendency to decrease BA with the age of reservoirs sampled $\left(r^{2}=0.23, p<0.0001\right)$. 
Bacterial Respiration and Specific Bacterial

\section{Respiration}

Mean values of Bacterial Respiration (BR) ranged from 20.7 to $82.42 \mathrm{mg} \mathrm{C} \mathrm{m-3} \mathrm{d-1.} \mathrm{Mean}$ values of Specific Bacterial Respiration (SBR) were significantly higher $(p<0.05)$ in the oldest reservoirs (Table 3 ). The rates varied from 1.83 to $4.54 \mathrm{fgC}$ cell h-1.

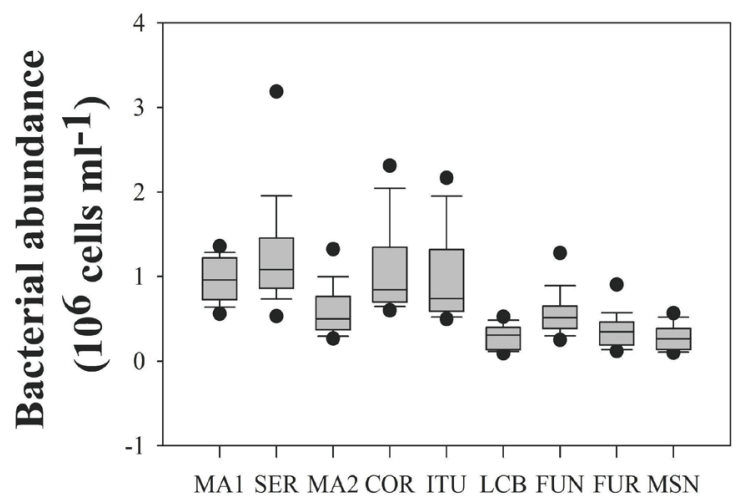

Figure 2. Box-plots of bacterial abundance in each reservoir (abbreviations as in Table 1). The variation is caused by seasonal and layer variation expressed by a box whisker plot, in which the line within boxes is the median, while the boxes, whiskers and dots encompass 75, 90 and 95\%, respectively. Reservoirs ordered from the youngest to the oldest.

Figura 2. Box-plots da abundância bacteriana em cada reservatório (abreviações como na Tabela 1). A variabilidade é causada pela sazonalidade e pela heterogeneidade espacial representada pelas caixas e barras, nas quais a linha dentro da caixa representa a mediana, enquanto a caixa, barras e pontos abrangem 75, 90 e 95\% dos valores, respectivamente. Os reservatórios foram ordenados dos mais jovens para os mais velhos.

\section{Bacterial Production}

Mean values of Bacterial Production (BP) ranged from 1.58 to $14.49 \mathrm{mg} \mathrm{C} \mathrm{m-3} \mathrm{d-).} \mathrm{As}$ shown in figure 3 , a wide variability was found among reservoirs for both BP and BR. BP and $B R$ rates showed similar variation among reservoirs such as indicate by the coefficient of variations 0.66 and 0.62 ( $p>0.05$, t-test), respectively.

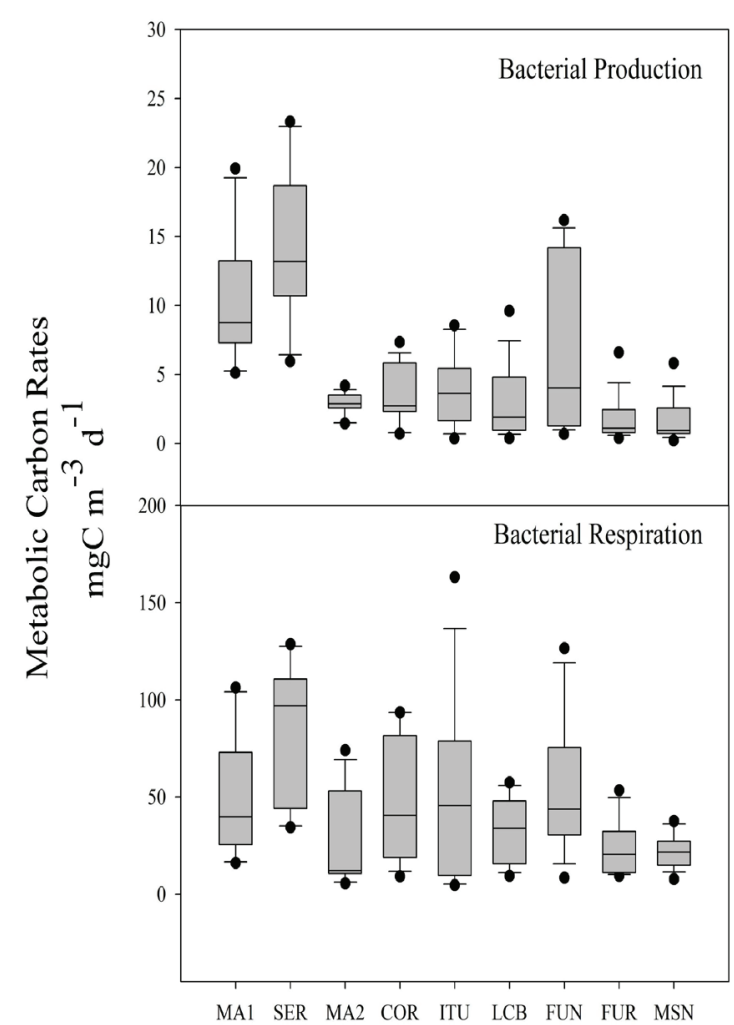

Figure 3. Box-plots of bacterial production and respiration in each reservoir (abbreviations as in Table 1). The variation is caused by seasonal and layer variation expressed by a box whisker plot, in which the line within boxes is the median, while the boxes, whiskers and dots encompass 75, 90 and 95\%, respectively. Reservoirs ordered from the youngest to the oldest.

Figura 3. Box-plots da produção e respiração bacteriana em cada reservatório (abreviações como na Tabela 1). A variabilidade é causada pela sazonalidade e pela heterogeneidade espacial representada pelas caixas e barras, nas quais a linha dentro da caixa representa a mediana, enquanto a caixa, barras e pontos abrangem 75, 90 e 95\% dos valores, respectivamente. Os reservatórios foram ordenados dos mais jovens para os mais velhos.

\section{Bacterial Growth Efficiency, BGE}

Considering mean values of BGE, by reservoir the values ranged from 7 to $21 \%$ (Figure $4 a$ ). There were no significant correlations between both BP and BR and reservoir age. However, higher efficiencies were observed in the youngest reservoirs MA1, MA2 and SER and in the eutrophic reservoir FUN. The high respiration rates in relation to production observed in the present study resulted in lower mean BGE value $(13 \%)$. 


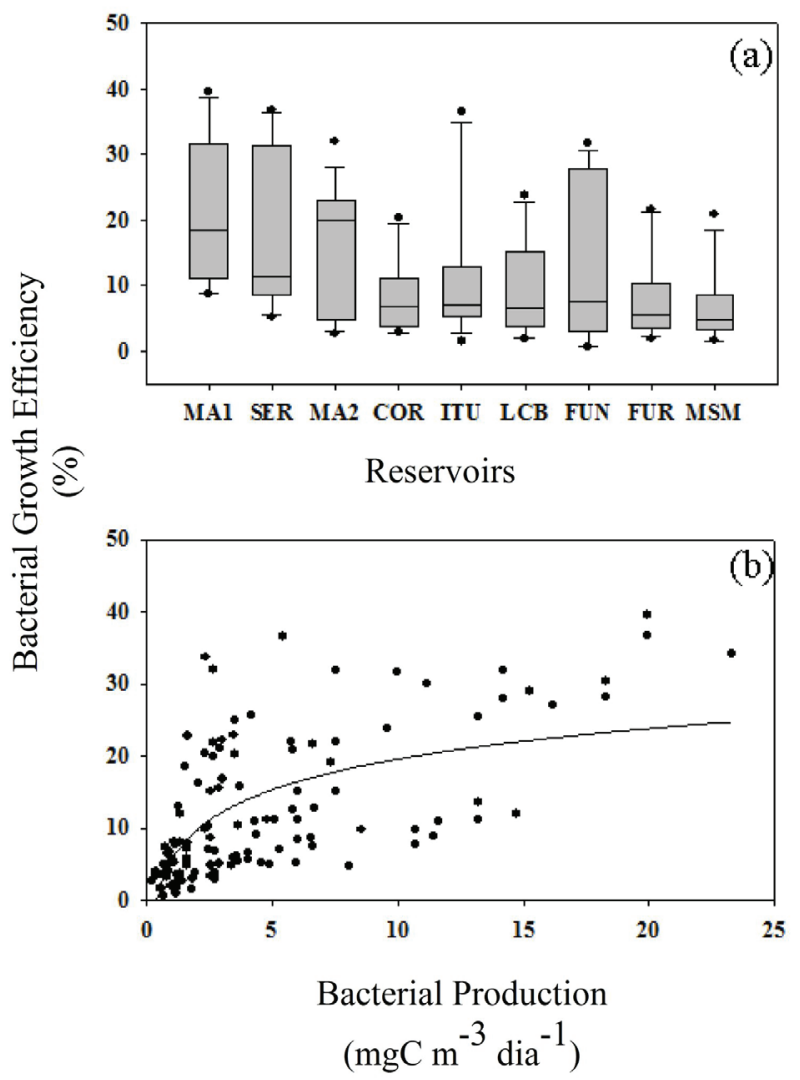

Figure 4. a) Box-plots of Bacterial Growth Efficiency in each reservoir (abbreviations as in Table I). The variation is caused by seasonal and layer variation expressed by a box whisker plot, in which the line within boxes is the median, while the boxes, whiskers and dots encompass 75,90 and 95\%, respectively. Reservoirs ordered from the youngest to the oldest. b) Relationship between Bacterial Production and Bacterial Growth Efficiency, considering the same data in (a).

Figura 4. a) Box-plots da eficiência de crescimento bacteriano em cada reservatório (abreviações como na Tabela 1). A variabilidade é causada pela sazonalidade e pela heterogeneidade espacial representada pelas caixas e barras, nas quais a linha dentro da caixa representa a mediana, enquanto a caixa, barras e pontos abrangem 75, 90 e 95\% dos valores, respectivamente. Os reservatórios foram ordenados dos mais jovens para os mais velhos. b) Relação entre a produção bacteriana e a eficiência de crescimento bacteriano, considerando os mesmos dados do gráfico (a).

\section{STATISTICS FACTS}

Combining all reservoirs and seasons, Spearman rank correlations (Table 2) showed that the magnitude of all BR, BP and BGE does not increase with increasing of total nutrients $(\mathrm{N}$ and $\mathrm{P}, \mathrm{p}=0.611$ and 0.783 , respectively), maybe because all reservoirs are relatively low enriched or high flushing systems. This feature does not allow accumulation of planktonic biomass. BGE and BA were negatively related to the age of the reservoirs $(r=-0.82$ and $-0.77 ; p<0.05)$. BP and BR rates were positively related to Chlorophyll-a ( $\mathrm{r}=0.80$ and 0.87 ; $\mathrm{p}<0.05)$ and to GPP $(\mathrm{r}=0.76$ and $\mathrm{r}=0.88, \mathrm{p}<0.05)$. On the other hand, BA was negatively related to GPP. Multiple regressions models confirmed that BA, SBR and BGE are a function of the age of reservoirs (Table 3), whereas BP was significantly related to BR and Mixing Zone. Besides, BR was negatively related to mixing zone. The One-Way ANOVA test showed that BP and BR rates are different among systems and the coefficients of variation indicated similar variability in the $\mathrm{BP}$ and $\mathrm{BR}$. 
Table 2. Spearman correlation coeficients between measured variables in eight reservoirs incluind all measurements throughout the study period. Asterisks: $* \mathrm{p}<0.05$. $* * \mathrm{p}<0.01$ and $* * * \mathrm{p}<0.001$. Abreviations are BP bacterial production. BR bacterial respiration. BGE bacterial growth efficiency. BA bacterial abundance. Chl-a chlorophyll-a concentration. GPP Gros Primary Production. TN total nitrogen. TP total phophorus. DOC. dissolved organic carbon. RT residence time and Watershed. n.s is no significant correlation.

Tabela 2. Coeficientes de correlação de Spearman entre as variáveis medidas nos oitos reservatórios. incluindo todas as medidas através do periodo de estudo. Asteriscos: ${ }^{*} p<0.05$. ${ }^{* *} p<0.01 e^{* * *} p<0.001$. Abreviações são BP produção bacteriana. BR respiração bacteriana. BGE eficiência de crescimento bacteriano. BA abudância bacteriana. Chl-a concentração de clorofila-a. GPP produção primária bruta. TN nitrogênio total. TP. fósforo total. DOC carbono orgânico dissolvido. RT tempo de residência e bacia hidrográfica. n.s é correlação não significativa.

\begin{tabular}{lcccc}
\hline & BP & BR & BGE & BA \\
\hline BP & - & & & \\
BR & $0.81^{* *}$ & - & - & - \\
BGE & - & - & $0.60^{*}$ & $n s$ \\
BA & $0.58^{*}$ & $0.68^{*}$ & $n s$ & $-0.75^{*}$ \\
Chl-a & $0.80^{* *}$ & $0.87^{* *}$ & $n s$ & $n s$ \\
GPP & $0.76^{*}$ & $0.88^{* * *}$ & $n s$ \\
TP & $n s$ & $n s$ & $n s$ & $n s$ \\
TN & $n s$ & $n s$ & $n s$ & $n s$ \\
DOC & $n s$ & $n s$ & $n s$ & $n s$ \\
Area & $n s$ & $n s$ & $n s$ & $n s$ \\
Volume & $n s$ & $n s$ & $n s$ & $n s$ \\
Watershed & $n s$ & $n s$ & $n s$ & $-0.77^{*}$ \\
RT & $n s$ & $n s$ & $-0.82^{* *}$ & $n s$ \\
Age & $n s$ & & $n s$ & $n$ \\
\hline
\end{tabular}

Table 3. Multiple regressions of bacterial abundance (BA), bacterial production (BP), bacterial respiration (BR), specific bacterial respiration (SBR) and bacterial growth efficiency (BGE) versus various explanatory variables: Only the best regression model were showed. Standard errors are in parentheses.

Tabela 3. Regressões múltiplasda abudância bacteriana (BA), produção bacteriana (BP), respiração bacteriana (BR), respiração bacteriana especifica (RBE) e eficiência de crescimento bacteriano (BGE) versus diversas variáveis explicativas. Somente os melhores modelos foram apresentados. Erros padrões estão entre parênteses.

\begin{tabular}{lccc}
\hline Equation & $\mathbf{r}^{2}$ & $\mathbf{r}^{2} \mathbf{a d j}$ & $\boldsymbol{p}$ \\
\hline $\mathrm{BA}=0.54+0.01( \pm 0.003) * \mathrm{BR}-0.01( \pm 0.004) *$ Age & 0.89 & 0.85 & $<0.01$ \\
$\mathrm{BP}=-7.61+0.21( \pm 0.05)^{*} \mathrm{BR}+0.22( \pm 0.18)^{*}$ Mixing Zone & 0.75 & 0.67 & $<0.01$ \\
$\mathrm{BR}=42.98+3.06( \pm 0.84)^{*} \mathrm{BP}-1.11( \pm 0.74)^{*}$ Mixing Zone & 0.78 & 0.70 & $<0.01$ \\
$\mathrm{SBR}=1.64+0.04( \pm 0.02)^{*}$ Age & 0.49 & 0.41 & $<0.01$ \\
$\mathrm{BGE}=18.58-0.21( \pm 0.08) *$ Age & 0.49 & 0.42 & $<0.01$ \\
\hline
\end{tabular}

\section{DISCUSSION}

\section{BACTERIAL METABOLISM IN ARTIFICIAL AQUATIC SYSTEMS}

The organic matter mineralization drives biogeochemical process like the production of greenhouse gases $\left(\mathrm{CH}_{4}, \mathrm{CO}_{2}\right.$ and $\mathrm{N}_{2} \mathrm{O}$ Lima et al. 2005). The degradation of the flooded organic matter before and after the reservoir constructions explains the emission of $\mathrm{CO}_{2}$ and $\mathrm{CH}_{4}$ which are send to the atmosphere in the first years of flooding (Rudd et al. 1993, Kelly et al. 1997, Rosenberg et al. 1997, St. Louis et al. 2000). Reservoirs also present wider 
variability of residence times than natural lakes as the former ones are depend on the construction proposal, e.g., irrigation or energy production. The major part of organic matter mineralization in lakes occurs in the water colum, but the sediments are the major sources of $\mathrm{CO}_{2}$ in reservoirs. (Åberg et al. 2005). However, the present study proved that carbon flux through bacterial community in hydroeletric reservoirs are important $\mathrm{CO}_{2}$ pathways to those aquatic ecosystems since reservoirs present higher respiration rates compared to BP.

\section{ARTIFICIAL VS. NATURAL AQUATIC ECOSYSTEMS}

The high respiration rates in relation to production observed in the present study resulted in lower mean BGE value (13\%) in relation to the average published by del Giorgio \& Cole (1998) of $25 \%$, and in low variation, from 7.5 to $20 \%$ compared to previous studies - see Table 4 (del Giorgio \& Cole 1998, Smith \& Prairie 2004, del Giorgio et al. 2006). Recent studies in many and different aquatic systems affirm the low mean bacterial efficiency and reaffirm the bacterioplankton role to the aquatic food chain and $\mathrm{CO}_{2}$ emission (Kritzberg et al. 2005, del Giorgio et al. 2006, Jansson et al. 2006, Smith \& Prairie 2004, Benner et al. 1995, Vidal et al. submitted). Thus, the present study proved that carbon flux through bacterial community in hydroeletric reservoirs are important $\mathrm{CO}_{2}$ pathways, as observed in aquatic systems with net primary production below 100 $\mu$ g C. $1^{-1} \mathrm{~d}^{-1}$ (del Giorgio et al. 1997). Transfer of bacterial biomass to higher trophic levels must be low. In terms of absolute values, the tendency changes when it was taken respiration by cell and reservoirs age (Figure 4). According to Cimbleris \& Kalff (1998), temperate ecosystems present higher specific bacterial respiration in oligotrohic systems, probably due higher maintenance costs relatively to eutrophic waters. Our findings confirm that higher specific bacterial rates were registered in the oldest reservoirs, also the most oligotrophic ones.
HYDROELECTRIC RESERVOIRS STRUCTURE AND FUNCTIONING MAY AFFECT BGES?

Bacterial parameters analyzed in this study (BP, BR and BGE) showed to be affected by age, chlorophyll-a and thermal structure of the reservoir. Both morphometric features and watershed size, as well the dam operation, are strong drivers of the temporal ecological evolution of reservoirs since the landscape are flooded. The terrestrial flooded biomass is an important allochthonous source of carbon to be metabolized during the first stages of the reservoirs. The amount of organic matter of the flooded organic matter can be a strong driver of bacterial production and BGE. The age of the hydroelectric reservoirs is known to be positively linked to that. Models that couple inland waters and drainage basin suggest a strong influence on the carbon metabolism in lakes (del Giorgio et al. 1999, Cole \& Caraco 2001, Sobek et al. 2005) and rivers (Raymond \& Cole 2003). Despite the high watershed: reservoir ratios in our study (26 to 1353), and the higher amounts arriving from the tributaries, carbon inputs were relatively low if compared, for example, to reservoirs in the Amazonian region (Rosa et al. 2004). One probable reason is the amount of organic carbon in Cerrado's soils, as mentioned before, varies from 4.3 to $5.3 \mathrm{~kg} \mathrm{C}$ $\mathrm{m}^{-2}$, if compared to mean values in the rich Amazonian soils (mean $=7.2$; range $=6.1$ to $9.2 \mathrm{~kg} \mathrm{~m}^{-2}$, http://www. sage.wisc.edu). Another factor that likely caused changes in bacterial metabolism co-occurred with the locations of significant sewage outfalls (Soares et al. 2008) like in the FUN reservoir, which presented one of the highest $\mathrm{BP}$ and $\mathrm{BR}$ rates.

\section{BP, BR AND BGE VARIABILITY}

The variability found among reservoirs to $\mathrm{BP}, \mathrm{BR}$ and BGE can be explained also by seasonal changes once the measurements were taken in contrasting conditions. During dry season, for example, the lower reservoir's water level in combination with the more constant river inflow leads to modest spatial variability, and the local influence of the riverine input 
is most evident during the dry season. On the other hand, the amplification of hydrological pulses during the rainy season facilitates mixing processes that alter spatial variability (Table 4). During the rainy season, the re-mineralization of the higher inflow of organic matter also increases the spatial variability. The combination between hydrodynamic processes and watershed dependence may also explain variability among the reservoirs.

In the present study, BP was not related to reservoir total nutrient concentrations or morphometric characteristics. On the other hand, it has been observed that BP $\left(1^{-1}\right)$ in temperate lakes have almost $80 \%$ of its variation explained by a combination of TP and lake mean depth or TN and residence time, variables that may largely reflect the supply of nutrients and substrate from the watershed (Cimbleris $\&$ Kalff 2003). The lack of such relationships in our reservoirs may due to the variable outflow rates caused by the dam and turbines operating regimes.

Our findings showed BP and BR variability is also explained by changes in chlorophyll- $a$. The dependence of bacterioplankton on autochthonous carbon has been evidenced by positive relationships between phytoplankton (expressed as chlorophyll $a$, cell numbers or biovolume) and heterotrophic bacteria (expressed as numbers, biomass and production; Bird \& Kalff 1984, Stewart \& Fritsen 2004). This is an indication that the growth of bacterioplankton is directly stimulated by phytoplankton (Cole et al. 1988, Jeppesen et al. 1997). Both autochthonous and allochthonous dissolved organic matter (DOM) support bacteria production. However, autochthonous DOM from phytoplankton is more available for bacterial consumption than is allochthonous terrestrial dissolved organic carbon (Kritzberg et al. 2005). This is because the molecules fixed by phytoplankton are less refractory compared to terrestrial dissolved organic carbon (Chen \& Wangersky 1996). In addition, humic substances in tropical freshwater ecosystems may be an important source of energy for aquatic bacteria (Amado et al. 2006). However, this source is probably not as important as carbon sources for bacterial production, since the consumption of humic substances is mostly channeled through microbial respiration (Farjalla et al. 2009).

Table 4. BGE literature review in aquatic ecosystems worldwide distributed.

Tabela 4. Revisão da literatura da eficiência de crescimento bacteriano em sistemas aquáticos distribuídos em todo mundo.

\begin{tabular}{lcc}
\hline Ecosystem & BGE $\mathbf{( \% )}$ & Reference \\
\hline Review (lakes, rivers, estuaries, oceans & $1-80$ & del Giorgio \& Cole, 1998 \\
Hudson River, USA & $7-23$ & Roland \& Cole, 1999 \\
Lakes, Wisconsin & $3-34$ & Kritzberg et al., 2005 \\
Hudson River, USA & $7-60$ & Del Giorgio et al., 2006 \\
Lakes, Quebec Canada & $6.7-51.6$ & Simith \& Prairie, 2004 \\
Humic, Southern Sweden & $0.4-10.4$ & Eiler et al. \\
Coastal lagoons & $2.3-26.6$ & Amado et al., 2006 \\
Amazon lake & $20.3-26.7$ & Farjalla et al. 2006 \\
Cerrado reservoirs & $2.5-28.7$ & This study
\end{tabular}

\section{CONCLUSION}

The present study contributes to an understanding of what regulates bacterial metabolism in hydroeletric reservoirs. This is the first study concerning bacterial metabolism (production, respiration and BGE) in tropical hydroeletric reservoirs. Moreover, few direct bacterial abundance and production measurements have been made in hydroelectric reservoirs. Our results showed that bacterial production and bacterial respiration variability were similar among reservoirs. However, BR rates were higher than BP resulting in 
low BGE values. Besides, BGE seems to be dependant on reservoir age. Future studies must be conducted considering contrasting reservoirs characteristics. We suggest future approaches to the contribution of hydroelectric reservoirs to bacterial metabolism: 1) spatial variability within the water body, including the effect in the water column caused by hydroelectric operating regimes; and 2) the geochemical features of their drainage basin in order to better understand metabolic bacterial process of organic matter in those systems.

ACKNOWLEDGEMENTS: We are grateful to J.J. Cole whose criticisms and insights greatly improved the manuscript. Financial support was provided by FURNAS Centrais Elétricas S.A. and grants from National Council of Research and Development (CNPq) Brazil. We also thank G. R. Marques for assistance in sample analyses and field work. This is a contribution to the Laboratory of Aquatic Ecology and Ecology Program of the Juiz de Fora University.

\section{REFERENCES}

ÅBERG, J.; BERGSTRÖM, A-K.; ALGESTEN, G.; SÖDERBACK, K. \& JANSSON, M. 2005. A comparison of the carbon balances of a natural lake (L. Örträsket) and a hydroelectric reservoir (L. Skinnmuddselet) in northern Sweden. Water Research, 38: 531-538.

AMADO, A.M.; FARJALLA, V.F.; ESTEVES, F.A.; BOZELLI, R.L.; ROLAND, F. \& ENRICH-PRAST, A. 2006. Complementary pathways of dissolved organic carbon removal pathways in clearwater Amazonian ecosystems: photochemical degradation and bacterial uptake. FEMS Microbiology Ecology, 56: 8-17.

BENNER, R.; OPSAHL, S.; CHIN-LEO, G.; RICHEY, J.E. \& FORSBERG, B.R. 1995. Bacterial carbon metabolism in the Amazon River system. Limnology and Oceanography, 40: 1262-1270.

BIRD, D.F. \& KALFF, J. 1984. Empirical relationships between bacterial abundance and chlorophyll concentration in fresh and marine waters. Canadian Journal Fisheries Aquatic Sciences, 41: 1015-1023.

BUKAVECKAS, P.A.; WILLIAMS, J.J. \& HENDRICKS, S.P. 2002. Factors regulating autotrophy and heterotrophy in the main channel and an embayment of a large river impoundment. Aquatic Ecology, 36: 355-369.

CHEN, W. \& WANGERSKY, P.J. 1996. Rates of microbial degradation of dissolved organic carbon from phytoplankton cultures. Journal Plankton Research, 18: 1521-1533.
CIMBLERIS, A.C.P. \& KALFF, J. 1998. Planktonic bacterial respiration as a function of $\mathrm{C}: \mathrm{N}: \mathrm{P}$ ratios across temperate lakes. Hydrobiologia, 384: 89-100.

CIMBLERIS, A.C.P. \& KALFF, J. 2003. Volumetric and areal rates of heterotrophic bacterial production in epi and hypolimnia: the role of nutrients and system morphometry. Hydrobiologia, 500: 193-202.

COLE, J.J.; FINDLAY, S. \& PACE, M.L. 1988. Bacterial production in fresh and saltwater ecosystems - a cross-system overview. Marine Ecology Progress Series, 43: 1-10.

COLE, J.J.; PACE, M.L.; CARPENTER, S.R. \& KITCHELL, J.F. 2000. Persistence of net heterotrophy in lakes during nutrient addition and food web manipulations. Limnology and Oceanography, 45: 1718-1730.

COLE, J.J. \& CARACO, N.F. 2001. Carbon in catchments: connecting terrestrial carbon losses with aquatic metabolism. Marine and Freshwater Research, 52: 101-110.

DEL GIORGIO, P.A. \& PETERS, R.H. 1993. The influence of DOC on the bacteria-chlorophyll relationship in lakes. Verhandlungen des Internationalen Verein Limnologie, 25: 359-362.

DEL GIORGIO, P.A.; COLE, J.J. \& CIMBLERIS, A. 1997. Respiration rates in bacteria exceed phytoplankton production in unproductive aquatic systems. Nature, 385: 148-151.

DEL GIORGIO, P.A. \& COLE, J.J. 1998. Bacterial growth efficiency in natural aquatic systems. Annual Review of Ecology and Systematics, 29: 503-541.

DEL GIORGIO, P.A.; COLE, J.J; CARACO, N.F. \& PETERS, R.H. 1999. Linking planktonic biomass and metabolism to net gas fluxes in northern temperate lakes. Ecology, 80: 1422-143.

DEL GIORGIO, P.A.; PACE, M.L. \& FISCHER, D. 2006. Relationship of bacterial growth efficiency to spatial variation in bacterial activity in the Hudson River. Aquatic Microbial Ecology, 45: 55-67.

DUARTE, C.D. \& AGUSTÍ, S. 1998. The CO2 balance of unproductive aquatic ecosystems. Science, 281: 34-236.

DI SIERVI, M.A.; MARIAZZI, A.A. \& DONADELLI, J.L. 1995. Bacterioplankton and phytoplankton production in a large Patagonian reservoir (Republica Argentina). Hydrobiologia, 297: 123-129.

DUMESTRE, J.F.; GUE'ZENNEC, J.; GALY-LACAUX, C.; DELMAS, R.; RICHARD, S. \& LABROUE, L. 1999. Influence of light intensity on methanotrophic bacterial activity 
in Petit-Sautreservoir, French Guiana. Applied Environmental Microbiology, 65: 534-539.

FARJALLA, V.F.; AMADO, A.M.; SUHETT, A.L. \& MEIRELES-PEREIRA, F. 2009. DOC removal paradigms in highly humic aquatic ecosystems. Environmental Science and Polluttion Research, 16: 531-538.

FINLAY, K.; LEAVITTI, P.R.; WISSEL, B. \& PRAIRIE, Y.T. 2009. Regulation of spatial and temporal variability of carbon flux in six hard-water lakes of the northern Great Plains. Limnology and Oceanography, 54(6): 2553-2564.

HOBBIE, J.E.; DALEY, R.J. \& JASPER, S. 1977. Use of Nuclepore Filters for Counting Bacteria by Fluorescence Microscopy. Applied and Environmental Microbiology, 33: 1225-1228.

JAHNKE, R.A. \& CRAVEN, D.B. 1995. Quantifying the role of heterotrophic bacteria in the carbon cycle: a need for respiration rate measurements. Limnology and Oceanography, 40: 436-441.

JANSSON, M.; BERGSTROM, A.K.; LYMER, D.; VREDE, K. \& KARLSSON, J. 2006. Bacterioplankton growth and nutrient use efficiencies under variable organic carbon and inorganic phosphorus ratios. Microbial Ecology, 52: 358-364.

JEPPESEN, E.; ERLANDSEN, M. \& SØNDERGAARD, M. 1997. Can simple empirical equations describe the seasonal dynamics of bacterioplankton in lakes: an eight-year study in shallow hypertrophic and biologically highly dynamic Lake Søbygård, Denmark. Microbial Ecology, 34: 11-26.

JONSSON, A.; MEILI, M.; BERGSTRÖM, A-K \& JANSSON, M. 2001. Whole lake mineralization of allochthonous and autochthonous organic carbon in a large humic lake (Örträsket, N. Sweden). Limnology and Oceanography, 46(7): 1691-1700.

JUGNIA, L-B.; RICHARDOT, M.; DEBROAS, D. \& DE'VAUX, J. 2006. Bacterial production in the recently flooded Sep Reservoir: diel changes in relation to dissolved carbohydrates and combined amino acids. Hydrobiologia, 563: 421-430.

JUGNIA, L-B. \& DE'VAUX, J. 2008. Bacterioplankton heterotrophic activity in relation to the phytoplankton compartment in a recently formed reservoir. Lakes \& Reservoirs: Research Management, 13: 13-22.

KELLY, C.A.; FEE, E.; RAMLAL, P.S.; RUDD, J.W.M.; HESSLEIN, R.H.; ANEMA, C. \& SCHINDLER, E.U. 2001. Natural variability of carbon dioxide and net epilimnetic production in the surface waters of boreal lakes of different sizes. Limnology and Oceanography, 46: 1054-1064.
KIRCHMAN, D.; KNEES, E. \& HODSON, R. 1985. Leucine Incorporation and Its Potential as a Measure of ProteinSynthesis by Bacteria in Natural Aquatic Systems. Applied and Environmental Microbiology, 49: 599-607.

KRITZBERG, E.M.; COLE, J.J.; PACE, M.M. \& GRANÉLI, W. 2005. Does autochthonous primary production drive variability in bacterial metabolism and growth efficiency in lakes dominated by terrestrial C inputs? Aquatic Microbial Ecology, 38: 103-111.

LAUSTER, G.H.; HANSON, P.C. \& KRATZ, T.K. 2006. Gross primary production and respiration differences among littoral and pelagic habitats in northern Wisconsin lakes. Canadian Journal Fisheries and Aquatic Science, 63: 1130-1141.

LIMA, I.B.T. 2005. Biogeochemical distinction of methane releases from two Amazon hydroreservoirs. Chemosphere, 59: 1697-1702.

RAYMOND, P.A. \& COLE, J.J. 2003. Increase in the export of alkalinity from North America's largest river. Science, 301: 88-91.

RICHARDOT, M.; DEBROAS, D.; JUGNIA, L-B.; TADONLE'KE"', R.D.; BERTHON, L. \& DE'VAUX, J. 2000. Changes in bacterial processing and composition of dissolved organic matter in a newly-flooded reservoir (a three-year study). Archiv für Hydrobiologie, 148: 231-248.

ROBARTS, R.D. \& WICKS, R.J. 1990. Heterotrophic bacterial production and its dependence on autotrophic production in a hypertrophic African reservoir. Canandian Journal Fisheries Aquatic Science, 47: 1027-1037.

ROLAND, F. \& COLE, J.J. 1999. Regulation of bacterial growth efficiency in a large turbid estuary. Aquatic Microbial Ecology, 20: 31-38.

ROSA, L.P.; DOS SANTOS, M.A.; DOS SANTOS, B.; MATVIENKO, E.O.; \& Sikar. E. 2004. Greenhouse gas emissions from hydroelectric reservoirs in tropical regions. Climatic Change, 66: 9-21.

ROSENBERG, D.M.; BERKES, F.; BODALY, R.A.; HECKY, R.E.; KELLY, C.A. \& RUDD, J.W.M. 1997. Large-scale impacts of hydroelectric development. Environmental Reviews, 5: 27-54.

RUDD, J.W.M.; HARRIS, R.; KELLY, C.A. \& HECKY, R.E. 1993. Are hydroelectric reservoirs significant sources of greenhouse gases? Ambio, 22: 246-248.

SMITH, D.C. \& Azam. F. 1992. A simple, economical method for measuring bacterial protein synthesis rates in seawater using 3H-leucine. Marine Microbial Food Webs, 6: 107-114. 
SMITH, E.M. \& PRAIRIE, Y.T. 2004. Bacterial metabolism and growth efficiency in lakes: The importance of phosphorus availability. Limnology and Oceanography, 49: 137-147.

SOARES, M.C.S.; MANZI, M.M.; HUSZAR, V.L.M.; BRANCO, C.W.; C \& Azevedo, S.M.F.O. 2008. The role of retention time and watershed characteristics on the limnology of two tropical reservoirs (Brazil). Lakes and Reservoirs: Research \& Management, 13: 257-269.

SOBEK, S.; TRANVIK, L.J. \& COLE, J.J. 2005. Temperature independence of carbon dioxide supersaturation in global lakes. Global Biogeochemical Cycles, 19: GB2003. doi:10.1029/2004GB002264

ST LOUIS, V.L.; KELLY, C.A.; DUCHEMIN, E.; RUDD, J.W.M. \& ROSENBERG, D.M. 2000. Reservoir surfaces as sources of greenhouse gases to the atmosphere: A global estimate. Bioscience, 50: 766-775.

STEWART, F.J. \& FRITSEN, C.H. 2004. Bacteria-algae relationships in Antarctic sea ice. Antarctic Sciences, 16: 143-156.

THORNTON, K.W. 1990. Perspectives on reservoir limnology. In: Thornton KW, Kimmel B, Payne F (eds) Reservoir limnology: ecological perspectives. Wiley, New York, pp 1-13.

TREMBLAY, A.; LAMBERT, M.; GAGNON, L. 2004. Do hydroelectric reservoirs emit greenhouse gases? Environmental Management, 33: 509-517.

VIDAL, L.O.; GRANÉLI, W.; DANIEL, C.; HEIBERG, L. \& ROLAND, F. Journal of Plankton Research, 33:1747 1756, 2011.

WILLIAMS, P.J. \& LE, B. 2000. Heterotrophic bacteria and the dynamics of dissolved organic matter. In: D. L. Kirchman (ed.). Microbial ecology of the oceans. Wiley. Pp. 153-200.

Submetido em 02/05/2011

Aceito em 09/07/2011 